\title{
Divine Unsurpassability
}

\section{Klaas J. Kraay}

Ryerson University

Please Cite:

Kraay, K. J. (2007). Divine unsurpassability. Philosophia, 35, 293-300. doi:10.1007/s11406-007-9084-6

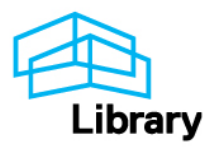




\section{DIVINE UNSURPASSABILITY*}

Klaas J . Kraay

Ryerson University

This paper appears in Philosophia 35 (2007): pp.293-300. The published version can be found online at: http:// www.springerlink.com/ content/ b10q662022118868/ fulltext.pdf.

One historically-significant model of God holds that God is a perfect being. Analytic philosophers of religion have typically understood this to mean that God is essentially unsurpassable in power, knowledge, goodness, and wisdom. Recently, however, several philosophers have argued that this is inconsistent with another common theistic position: the view that for any world that God can create, there is a better world that God could have created instead. The argument runs (roughly) as follows: if, no matter which world God creates, there's a better creatable one, then God's action in creating a world is necessarily surpassable. And if God's action in creating a world is necessarily surpassable, then God is necessarily surpassable. If this argument is sound, it reveals a serious flaw in an important model of God. In what follows, I set out this argument, and I then distinguish and evaluate four replies.

Traditional versions of J udaism, Christianity, and Islam all maintain that God is a perfect being. Famously, Anselm understood this doctrine to mean that God is a being than which none greater is conceivable. Assuming that conceivability does not exhaust possibility, a more robust expression of this doctrine holds that God is a being than which none greater is possible. Proponents of the latter say that, necessarily, God is unsurpassable with respect to various attributes, such as power, knowledge, goodness, and wisdom. This may be termed essential divine unsurpassability - henceforth EDU - and a faith which upholds it may be termed EDUtheism.

The best-known arguments against EDU-theism are a posteriori. Commonly grouped under the heading "problem of evil", they claim that this doctrine is untenable, given certain facts about suffering. These arguments are notoriously controversial. I set them aside in what follows, however, in order to consider a different, a priori criticism. This purports to be a swift and total reductio of EDU-theism, given some plausible claims. Moreover, if EDU is nonnegotiable (as many theists believe) then this argument's target is theism itself. I first set out this argument, and I then distinguish and evaluate four replies.

\section{The A Priori Argument Against EDU-THEISM}

Some theists have held, with Leibniz, that there is exactly one best of all creatable worlds. But many disagree, and hold that for any world God can create, there is a better world that God could have created instead. Philip Quinn (1982), Stephen Grover (1988), William Rowe (1993, 2004), and Jordan Howard Sobel (2004) have argued that this latter view precludes EDUtheism. Their central intuition is this: if, no matter which world God creates, there's a better creatable one, then no matter what God does, God's action in creating a world is surpassable. And if God's action in creating a world is necessarily surpassable, then God is necessarily surpassable. ${ }^{1}$ This intuition can be formalized with reference to the following set of propositions: 
NBW For every world $w$ that is within God's power to actualize, there is a better world, $\mathrm{x}$, that God has the power to actualize instead. ${ }^{2}$

P1 If it is possible for the product of a world-actualizing action performed by some being to have been better, then, ceteris paribus, it is possible for that being's action to have been better. ${ }^{3}$

P2 If it is possible for the world-actualizing action performed by some being to have been better, then, ceteris paribus, it is possible for that being to have been better.

G There possibly exists a being who is essentially unsurpassable in power, knowledge, goodness, and rationality.

Critics of EDU-theism urge that since this set is inconsistent, and since P1 and P2 are plausible principles, those who endorse NBW ought to reject G. This amounts to an a priori argument for the impossibility of EDU-theism, given NBW. ${ }^{4}$

\section{RePlies to the A PRiori ARgument AgAinst EDU-THEISM}

How might the theist reply? Four ways are briefly sketched below. First, the EDU-theist might reject NBW (the ontology assumed by this argument) and instead hold, with Leibniz, that there is a unique best of all worlds that God can actualize. ${ }^{5}$ But the difficulties facing this move are well-known. There are a priori concerns: it is widely-assumed on this view that God would actualize the best world, but in doing so, would God really act freely?6 (And if not, is God's choice really a good one?) There are also familiar a posteriori concerns: if there is a best of all actualizable worlds, why doesn't this one seem to be it? ${ }^{7}$

Second, the EDU-theist might defend G. The argument against EDU-theism is ambitious: it seeks to show that no such God is possible on NBW. But the theist might try to reverse the argument: she might claim that $\mathrm{G}$ - a modest proposition - is better-supported than P1 and P2. How might she defend G? Of course, a good argument for the actual existence of an essentially-unsurpassable deity would do, since this would establish a fortiori that such a being is possible. Alternatively, she might try to justify the inference from conceivability to possibility in this context, granting that an essentially-unsurpassable deity is conceivable. Finally, following Plantinga (2000), she might argue that G can be a properly basic belief for the theist, given certain conditions. If any such strategy makes it reasonable for the theist to maintain G over P1 and P2, then the argument against EDU-theism fails. This response is unlikely to satisfy the EDU-theist, however, since it fails to diagnose any specific defect in the argument against EDUtheism.

Third, the EDU-theist might sacrifice her commitment to EDU (in other words, concede $\sim G$ ) in order to save her theism. She might concede that $G$ is precluded by the conjunction of $P 1$, $\mathrm{P} 2$, and NBW, and grant that the latter three are plausible. But she might then construct an account of divine perfection that does not involve EDU, or some other notion of God altogether. ${ }^{8}$ This move is unlikely to please most traditional monotheists, however, since they typically consider EDU non-negotiable.

Finally, the most natural response for the EDU-theist is a direct attack on P1 or P2. Any such move, however, must provide independent reason for rejecting one of these principles: it is question-begging to reject their conjunction merely because it precludes G (granting NBW) . ${ }^{9}$ An attack on P1 or P2 may take one of two forms: it may suggest that their conjunction is 
unmotivated (or defeated) by reflection on human cases, ${ }^{10}$ or it may allege that their conjunction is implausible in the divine case. The remainder of this paper considers only the latter alternative, only with respect to P1.

In Section 3, I outline a recent objection to P1; in Section 4, I offer a reply. In Section 5 I develop a modified objection to P1; in Section 6 I offer a reply. I will show that the theist is best advised to pursue an altogether different response to P1, or an objection to P2, or one of the other replies outlined above.

\section{AN OBJ ECTION TO P1BASED ON LIBERTARIAN FREE WILL}

The theist might object to P1 by appeal to considerations about free will. Brian Leftow, for example, argues that P1 objectionably assumes that God has complete control over the axiological status of the product of his world-actualizing action. ${ }^{11} \mathrm{He}$ points out that the moral worth of actions performed by free creatures in that world is an important contributor to the overall axiological status of a world. But given libertarian freedom, which many theists accept, it follows that this significant determinant of the overall status of a world is, quite simply, beyond God's control. ${ }^{2}$ Accordingly, it is possible for the product of God's world-actualizing activity to have been better, even though God's action (in actualizing the world and the libertarian-free moral agents it contains) could not have been better. ${ }^{13}$ If this is plausible, $\mathrm{P} 1$ can be rejected.

\section{REPLY TO THE OBJ ECTION TO P1}

The objection assumes that (a) it is possible for God to create libertarian-free agents, and that (b) this is a good thing for God to do, all else equal. Further, it assumes that (c) there are no actualizable worlds lacking such creatures that surpass all the worlds which contain them. ${ }^{14}$ (Otherwise, one would not expect God to create libertarian-free agents, in which case the objection is moot.) These assumptions may be controversial, but I grant them in what follows, since they are widely held by theists. Accordingly, libertarian freedom is presumed below.

This objection aims to depict a scenario according to which the antecedent of P1 is true, while its consequent is false. But how are considerations about creaturely freedom supposed bear on the antecedent of $\mathrm{P} 1$, which concerns the product of a divine world-actualizing action? The objection contends that the better creaturely actions are, ceteris paribus, the better this product will be. Notice, however, that this assumes the product of a divine world-actualizing action to be the entire world under consideration, including the actions of creatures.

This assumption, however, is illegitimate: the actions of creatures are not properly considered part of the product of God's world-actualizing action. ${ }^{15}$ Libertarian actions are - by definition - outside God's control. ${ }^{16}$ This is why, standardly, God and creatures are taken to be collaborators in the actualization of a world: both play a role in determining which world is actual. God is responsible, inter alia, for a world's being the way it is prior to the introduction of creatures, and God is also responsible for the introduction of such creatures: all this properly counts as the product of God's world-actualizing action. But when such creatures are introduced and act freely, they also help make it the case that one world rather than another is actual, and such determinations count as the product of their world-actualizing actions, not God's. The resulting world, then, is partly the product of God's actions, and partly the product of creatures' actions.

If this distinction is plausible, then the objection to P1 described in Section 3 fails. The actions of libertarian-free agents can indeed affect the overall axiological status of a world, as the objection supposes. But this is irrelevant to the antecedent of P1, which refers to the product of God's world-actualizing action. The question is not whether the product of God's world- 
actualizing action can be better in virtue of what libertarian-free creatures do: the question is whether the product of God's world-actualizing action can be better in virtue of what God does. So far, then, we have no reason for rejecting $\mathrm{P} 1$.

\section{A MODIFIEd OBJ ECTION TO P1}

Perhaps this distinction between divine and creaturely contributions to world-actualization can motivate a modified objection to P1. Theists standardly hold that while God could prevent, eliminate, or reduce certain evils in a world by fiat, God might refrain from doing so, given sufficient reason. This position is common in the vast literature on the problem of evil. For example, a theist might say that God refrains from preventing, eliminating, or reducing certain evils by fiat in order for (or, more weakly, in order to allow) creatures to prevent, eliminate, or reduce these evils. Similarly, theists often maintain that while God could introduce or augment certain goods in a world by fiat, God might refrain from doing so, given sufficient reason. For example, a theist might hold that God refrains from introducing or augmenting certain goods, in order for (or in order to allow) creatures to introduce or augment these goods. ${ }^{17}$ Perhaps this is a model of how the product of God's world-actualizing activity (narrowly construed to exclude the world-actualizing contributions of creatures) could have been better, without it following that God's action could have been better overall.

\section{REPLY TO THE MODIFIED OBJ ECTION TO P1}

The modified objection to P1, like its predecessor, purports to offer a model according to which the antecedent of P1 is true, while its consequent is false. But the model illustrates just one respect in which the product of God's world-actualizing action could have been better, without it (purportedly) following that God's action could have been better overall. Here's the problem: it's plausible to think that there are other respects in which the product of God's action could have been better, and that in at least one of those respects, God's action would have been better overall. ${ }^{18}$ If so, the modified objection to P1 fails.

To see why, grant everything the EDU-theist suggests in the modified objection. Grant that God has sufficient reason for failing to introduce or augment certain goods (or for failing to prevent, eliminate, or reduce certain evils). Suppose, indeed, that God does so in order for (or in order to allow) creatures to do their part better. This represents one respect in which the product of God's action could have been better, and thus far we have no reason to think that God's action could have been better, since God has morally sufficient reason for refraining in this manner.

But, is it reasonable to think there are other respects in which the product of God's world-actualizing action could have been better? Yes. Perhaps it's the case that no matter what God does, God could always create more intelligent, conscious, free, happy creatures, ${ }^{19}$ more beautiful things, ${ }^{20}$ better things altogether, ${ }^{21}$ and so forth. (These are plausible good-making features of worlds, and are the sort of features that typically motivate NBW.) It's reasonable to think that, for at least one such respect in which God could bring about a better product, it follows that God's doing so constitutes a better action overall. This is so even if God is justified in doing less than he is able, in the specific manner described in the modified objection. In short, the modified objection fails. 


\section{CONCLUSION}

The objections to P1 discussed above commit equal and opposite errors. The initial objection treats "the product of God's world-actualizing action" too broadly, by taking it to mean the entire world under consideration (and, accordingly, by failing to distinguish divine contributions to world-actualization from creaturely contributions). But the modified objection treats "the product of God's world-actualizing action" too narrowly, by concentrating only on certain respects in which God might reasonably refrain from bringing about a better product (and, accordingly, by assuming that there could not be other respects in which God could bring about a better product and thereby perform a better action on the whole). Neither, then, is satisfactory. For this reason, the defender of divine unsurpassability is best advised to pursue some other objection to P1, or an objection to P2. Alternatively, she might pursue one of the other responses sketched in Section 2, but their drawbacks have been noted. The a priori argument against EDU-theism remains a formidable challenge.

* I thank Bernard D. Katz, Elmar Kremer, and J ordan Howard Sobel for stimulating discussion of many issues germane to this paper. I thank Paul Bali, Nathan Ballantyne, Luke Gelinas, and Andrew Hunter for helpful comments on earlier drafts. These drafts were presented to (a) the Mini-Conference on Models of God, within the American Philosophical Association Pacific Division Meeting (San Francisco, CA, April 3-5, 2007); and to (b) the Society of Christian Philosophers Midwestern Division Meeting (Notre Dame, IN, April 20-22, 2006). I am grateful to all my interlocutors on those occasions, especially Mike Rea and Charles Taliaferro, and to J eanine Diller, for her exemplary work in organizing the former conference. Finally, I am grateful for the generous research support I received from (a) Ryerson University's SSHRC Institutional Grant (2005-2006), and from (b) the Social Sciences and Humanities Research Council of Canada (2005-2007).

\section{$\underline{\text { NOTES }}$}

${ }^{1}$ Grover has recently distanced himself from this latter claim, noting that the former alone is problematic for theism (2004: 103, 105).

2 Strictly speaking, possible worlds can neither be created nor destroyed, so convention has it that worlds are "actualized". God cannot refrain from actualizing a world: even if God creates nothing, the resulting world (populated only by God and whatever other uncreated necessary existents there are) is the actual world. In what follows, I assume - for simplicity only - that all worlds have objective axiological status, that all worlds are commensurable and comparable, and that there are no ties.

3 Two clarifications are in order. First, this proposition may sound consequentialist, but it is not wedded to any particular account of the relationship between the goodness of outcomes and the goodness of actions. For more in this vein, see Conee (1994: 821). Second, the consequent of P1 claims that it is possible for an action to have been 'better', and the consequent of $\mathrm{P} 2$ claims that it is possible for a being to have been 'better'. While Rowe $(1993,2004)$ understands these claims to concern moral surpassability, Sobel (2004: 468ff) takes them to concern rational surpassability. Everything below is consistent with both interpretations.

${ }^{4}$ It is important to see that this argument does not reduce to the traditional problem of evil. First, as noted, it proceeds entirely a priori, while arguments from evil generally contain at least one a posteriori 
premise about the existence, scope, or distribution of evil. Second, this argument concludes that an essentially-unsurpassable God is impossible - a much stronger conclusion than arguments from evil can warrant. Third, this argument could be advanced even if evil were metaphysically impossible. It is an argument from improvability, rather than from evil.

5 Grover (1988) recommends this. Alternatively, one might hold that there is more than one unsurpassable actualizable world.

6 Rowe (2004: 74-87) criticizes Robert Adams' (1972) famous argument for the claim that God is free to actualize a world other than the best one.

${ }^{7}$ I do not mean to suggest that these concerns are unanswerable, but they are powerful and must be taken seriously by the defender of EDU-theism.

${ }^{8}$ For example, see Hasker (2004) and Kraay (2005b).

9 This charge is developed against Morris (1993) and Langtry (1996) in Kraay (2005a).

${ }^{10}$ Hasker (2004) takes this route.

11 "All of these arguments assume that God has complete control over how much good he does by creating. Only in this way can Rowe and Leibniz take it that differences in worlds' goodness must express differences in their creators' wisdom or goodness. If a creator need not get quite the world it wants, then even if two equally wise and good creators try to actualize just the same states of affairs, they need not get the same resulting world. If they need not, it is just false that different worlds entails different moral [or rational] stature" (Leftow 2005a, 168).

12 'In many cases, the difference in worlds' moral value consists in creatures' right and wrong acts, or the moral good inherent in creatures' doing certain acts. In these cases, divine activity can account for the whole moral difference between worlds only if it can wholly account for creatures' doing what they do. It wholly accounts for this iff God causes creatures to act" (Leftow 2005a, 172). And, of course, if creatures have libertarian freedom, then it is false that God causes creatures to act.

13 Suppose that the actual world contains libertarian-free creatures who all could have done much better, morally, than they did. If so, this world could presumably have been better - in other words, the antecedent of P1 is true. But thus far we have no reason to think the consequent of P1 true: God's action in actualizing this world and the free agents it contains need not be impugned by the creatures' misuse of their freedom. So goes the argument against P1 in Leftow (2005a) and (2005b).

${ }^{14}$ Leftow appears committed to this, although he concedes that some worlds without libertarian-free creatures surpass some worlds which contain them (2005b, 280).

${ }^{15}$ A rough analogy: the actions of libertarian-free children are not properly considered part of the product of their parents' child-actualizing action.

${ }^{16}$ Of course, these actions are under divine control in that God could destroy such creatures, or fail to create them - but this sense of 'control' is not relevant. Leftow (2005b) considers Molinism: the doctrine according to which there are unalterable contingent truths (known by God) about how libertarian free creatures would act in various possible circumstances. On Molinism, God can control creatures' actions without causing them: by actualizing the world in which his favoured creaturely counterfactuals of freedom obtain. But Leftow (2005a, 174) urges that Molinism precludes genuine creaturely moral responsibility, and is hence unacceptable to theists. 
${ }^{17}$ Stories along these lines are sometimes called theodicies, sometimes defences (depending on whether they are asserted to be true, or merely possible). They are typically criticized for failing to specify a sufficiently plausible account of how God is, or might be, justified in doing less than God can. I set such criticisms aside here, since in the next section I will show, on purely formal grounds, that these stories cannot establish that $\mathrm{P} 1$ is false.

18 Consider Leftow's variant of P1:

(7a) Necessarily, for all $\mathrm{xy}$, if in $\mathrm{W} x$ actualizes world $\mathrm{W}$ and in $\mathrm{W}^{*} \mathrm{y}$ instead actualizes $\mathrm{W}^{*}$, and $\mathrm{W}^{*}$ is a morally better world than $\mathrm{W}$, and nothing else distinguishes these actions morally, $\mathrm{y}^{\prime}$ s action in $\mathrm{W}^{*}$ is morally better than x's action in W (2005a: 171, emphasis added).

Leftow takes it that the 'moral differences' between worlds are fully attributable to the actions of libertarian-free creatures (172), and he assumes that nothing other than these differences distinguishes the actions of $\mathrm{x}$ and $\mathrm{y}$ morally. But, as I argue here, the latter assumption is unreasonable: there may well be other ways to distinguish the moral characteristics of the world-actualizing actions of $\mathrm{x}$ and $\mathrm{y}$.

${ }^{19}$ Richard Swinburne takes this view (1979: 114), and it is his reason for endorsing NBW.

20 Worlds can contain entities which bear aesthetic properties, and perhaps God's ability to create (quantitatively) more of these, or (qualitatively) more beautiful entities, is without limit. Equally, perhaps entire worlds bear aesthetic properties, and perhaps there is no limit to what God can do with respect to these.

${ }^{21}$ Norman Kretzmann takes Aquinas to hold that God could make each thing in the world a better instance of what it is (1991: 229-249.) Perhaps there is no upper bound on what an omnipotent being can do in this regard.

\section{REFERENCES}

Adams, R. (1972). Must God Create the Best?, Philosophical Review, 81, 317-332

Conee, E. (1994). The Nature and Impossibility of Moral Perfection, Philosophy and Phenomenological Research, 54, 815-825

Grover, S. (1988). Why only the Best is Good Enough, Analysis, 48, 224

(2004). Rival Creator Arguments and the Best of all Possible Worlds, Sophia, 43, 101114

Hasker, W. (2004). The Freedom and Goodness of God. (In his Providence, Evil, and The Openness of God (pp. 167-186). New York, Routledge.)

Kraay, K. (2005a). William L. Rowe's A Priori Argument for Atheism, Faith and Philosophy, 22, 211-234 (2005b). Theistic Replies to the A Priori Argument for Atheism, Philo, 8, 22-36

Kretzmann, N. (1991). A Particular Problem of Creation. (In S. MacDonald (Ed.), Being and Goodness (pp. 229-249). Ithaca, Cornell University Press.) 
Langtry, B. (1996). God and the Best, Faith and Philosophy, 13, 311-328

Leftow, B. (2005a). No Best World, Moral Luck, Religious Studies, 41, 165-181 (2005b). No Best World, Creaturely Freedom, Religious Studies, 41, 269-285

Morris, T. (1993). Perfection and Creation. (In E. Stump (Ed.), Reasoned Faith (pp. 234-247). Ithaca, Cornell University Press.)

Plantinga, A. (2000) Warranted Christian belief. New York: Oxford.

Quinn, P. (1982). God, Moral Perfection, and Possible Worlds. (In F. Sontag and M.D. Bryant (Eds.), God, The Contemporary Discussion (pp. 197-213). New York, The Rose of Sharon Press, Inc.)

Rowe, W. (1993). The Problem of Divine Perfection and Freedom. (In E. Stump, (Ed.). Reasoned Faith (pp. 234-247). Ithaca, Cornell University Press.)

(2004). Can God Be Free?. (Oxford, Oxford University Press)

Sobel, H. (2004). Logic and Theism, Arguments for and Against Beliefs in God. (Cambridge, Cambridge University Press)

Swinburne, R. (1979). The Existence of God. (Oxford, Clarendon Press) 